\title{
Portal vein thrombosis with ruptured oesophageal varices as presenting manifestation of hereditary protein C deficiency
}

\author{
D VALLA, M-H DENNINGER, J-M DELVIGNE, B RUEFF, \\ AND J-P BENHAMOU
}

From the Service d'Hépatologie and the Unité de Recherches de Physiopathologie Hépatique; and the Service d'Immuno-Hématologie, Hôpital Beaujon, Clichy, France

SUMMARY The protein $\mathrm{C}$ system is essential in limiting the activation of coagulation in vivo. We report the case of a 45 year old man with portal vein thrombosis complicated by ruptured oesophageal varices. Low concentration of plasma protein $\mathrm{C}$ was found in the patient and subsequently in one brother with a history of venous thromboembolism, and also in one son and one nephew who were asymptomatic. Hereditary protein $\mathrm{C}$ deficiency should be considered in patients with portal hypertension due to portal vein thrombosis.

In up to $50 \%$ of adults with portal vein thrombosis, the cause of vascular obstruction cannot be elucidated. ${ }^{1-3}$ Protein $\mathrm{C}$ had recently been identified as a major factor regulating thrombin generation. Hereditary deficiency in protein $\mathrm{C}$ was associated with a high risk of thromboembolic disease. ${ }^{+6}$ Manifestations include superficial thrombophlebitis, deep venous thrombosis, and/or pulmonary embolism,,$^{+6}$ cerebral venous thrombosis,${ }^{78}$ and mesenteric vein thrombosis. ${ }^{910}$ Protein $\mathrm{C}$ is a vitamin $\mathrm{K}$-dependent zymogen of a serine protease ${ }^{11}$ and is synthesised in the liver. ${ }^{12}$ It is converted to its activated form in a reaction catalysed by a complex formed between thrombin and thrombomodulin, an endothelial cell surface protein. ${ }^{13}{ }^{14}$ Activated protein $\mathrm{C}$ inhibits activated factors $\mathrm{V}$ and $\mathrm{VIII}^{15}$ and stimulates fibrinolysis through the inactivation of the tissue plasminogen activator ( $t-P A)$ inhibitor..$^{16} 17$

In a prospective study of 40 consecutive adult patients with portal vein thrombosis, we have identified one patient with hereditary protein C deficiency, whose case is reported here.

Address for correspondence: Dr Jean-Pierre Benhamou. INSERM U 24 , Hôpital Beaujon, 92118 Clichy, France.

Received for publication 4 December 1988.

\section{Case report}

In December 1986, a 45 year old man (Figure, II-4) was admitted to Hôpital Beaujon for melaena. In 1984, he suffered from an unexplained bout of abdominal pain. In May 1986, after a first episode of melaena, endoscopy showed oesophageal varices; serum gamma glutamyl transpeptidase was three times the upper limit of normal; the patient received 2 units of packed red blood cells. There was no personal history of venous thromboembolism, but one older brother (Figure II-2) had suffered from deep venous thrombosis of the leg complicated by pulmonary embolism and from myocardial infarction at ages 55 and 56 , respectively.

On admission, clinical examination was normal. Laboratory tests gave the following results: erythrocyte count $4.8710^{9} / \mathrm{l}$, haemoglobin $15 \cdot 1 \mathrm{~g} / \mathrm{dl}$, leucocyte count $6.810^{9} / 1$, platelet count $15410^{\circ} /$; ALT 35 IU/l $(\mathrm{N}<40 \mathrm{IU})$, serum alkaline phosphatase $101 \mathrm{IU} / \mathrm{l}(\mathrm{N}<130 \mathrm{IU})$, serum albumin $4 \cdot 0$ $\mathrm{g} / \mathrm{dl}$, serum globulin $1.2 \mathrm{~g} / \mathrm{dl}$; prothrombin time was found in the normal range. Fibroscopy showed large oesophageal varices and no other lesion. Ultrasound examination disclosed atrophic right liver lobe, 


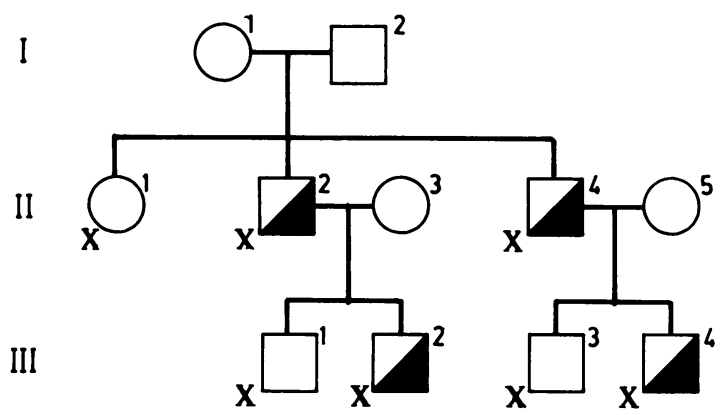

Figure Pedigree of the proband (II-4) presenting with portal cavernoma: $\mathbf{\square}$ heteroxygote for protein $C$ deficiency. $X=$ investigated .

patent hepatic veins, obliterated right portal vein but patent left portal vein. The portal vein could not be identified in the porta hepatis which was occupied by several abnormal tubular structures suggestive of cavernous transformation. Abdominal computed tomography scan confirmed the presence of a portal cavernoma. The gradient between wedged and free hepatic venous pressure was $2 \mathrm{mmHg}$ (normal, 2-4 $\mathrm{mmHg}$ ). Histologic examination of a liver specimen showed no abnormality.

Search for a myeloproliferative disease using determination of total red cell mass, bone marrow biopsy and cultures of bone marrow cell ${ }^{18}$ was negative. There was no laboratory evidence of paroxysmal nocturnal haemoglobinuria or lupus anticoagulant. As shown in the Table, a type I protein $\mathrm{C}$ deficiency was found, ${ }^{19}$ as functional ${ }^{20}$ and immunoenzymatic $^{21}$ assays gave low values for plasma protein C. There was no deficiency in protein $\mathrm{S}_{, 22}$ antithrombin III, ${ }^{23}$ plasminogen, ${ }^{24}$ or heparin cofactor II. ${ }^{25}$

During the hospital stay, the patient developed thrombosis of the left superficial femoral vein. He was treated with intravenous sodium heparin and, subsequently, with propranolol and coumarin.

A study of the patient's family showed deficiency in protein $\mathrm{C}$ in the brother of the proband (Figure, II-2), in one asymptomatic son aged 24 (Figure, III-4), and in one asymptomatic nephew aged 32 (Fig. III-1). Proband's father died at age 69 from silicosis. Proband's mother, aged 85, was alive with varicose veins and trophic cutaneous ulcers of the legs; she could not be tested for protein C.

\section{Discussion}

Deficiency in protein $\mathrm{C}$ can be inherited and is then most often transmitted as an autosomal dominant trait with various penetrance. ${ }^{641026} \mathrm{~A}$ low level of plasma protein $\mathrm{C}$ can also be acquired as a result of
Table Results of coagulation studies in 4 affected members of the family

\begin{tabular}{|c|c|c|c|c|c|}
\hline & \multirow{2}{*}{$\begin{array}{l}\text { Normal range } \\
\begin{array}{l}\text { Percent of } \\
\text { normal }\end{array}\end{array}$} & \multicolumn{4}{|c|}{ Family mermber } \\
\hline & & $I I-2$ & $I I-4$ & $I I I-2$ & $111-4$ \\
\hline Factor II & $70-120$ & 90 & 76 & & 87 \\
\hline Factors VII +X & $7(0-120$ & 90 & 91 & & 100 \\
\hline Factor V & 7()$-120$ & 95 & 67 & & 79 \\
\hline Protein $\mathrm{C}$ antigen & $65-120$ & 50 & 37 & 55 & 32 \\
\hline Protein C activity & 7()$-120$ & 41 & 45 & 65 & 42 \\
\hline Protein $\mathrm{S}$ antigen & $65-120$ & 110 & 82 & & 105 \\
\hline Plasminogen activity & 7()$-120$ & 85 & 67 & & 88 \\
\hline $\begin{array}{l}\text { Heparin cofactor II } \\
\text { activity }\end{array}$ & $70-120$ & & 69 & & 118 \\
\hline \multicolumn{6}{|l|}{ Antithrombin III } \\
\hline & $g / l$ & & & & \\
\hline Fibrinogen & $2-4$ & $4 \cdot 20$ & 2.95 & & $3 \cdot 20$ \\
\hline
\end{tabular}

disseminated intravascular coagulation, ${ }^{27}$ which was not present in any of the affected members of this family. More commonly, deficiency in protein $\mathrm{C}$ is the consequence of liver disease and is then associated with decreased level of other coagulation factors. Impairment of liver function which can result from portal vein thrombosis, ${ }^{2 x}$ cannot account for the low protein $\mathrm{C}$ level in our patients, as the levels of other coagulation factors were normal. In this family, protein $\mathrm{C}$ deficiency was found in two asymptomatic young men, in one patient with a typical history of thromboembolism, and in the proband with portal cavernoma, a likely sequella of earlier thrombosis (Figure). Thus, protein C deficiency detected in the propositus is compatible with a defect inherited as an autosomal dominant trait.

It is not clear whether the unexplained bout of abdominal pain which occurred two years before corresponded to the constitution of thrombosis, to a resolutive episode of intestinal ischaemia secondary to mesenteric vein thrombosis, or to an unrelated illness. There are other cases of deficiency in protein $\mathrm{C}$, protein $\mathrm{S}$, or antithrombin III, manifested by mesenteric vein thrombosis. ${ }^{91124,32}$ In these latter cases, the manifestations were those of acute intestinal ischaemia or infarction. Among our 40 patients with portal vein thrombosis prospectively tested for protein $\mathrm{C}$, this is the first case of chronic portal hypertension caused by hereditary protein C deficiency and we are not aware of any similar reported case. Only one case of portal hypertension consecutive to portal vein thrombosis and related to an inherited protein $\mathrm{S}$ deficiency has already been reported; the patient was a young girl suffering from recurrent variceal bleeding from age $10 .^{29}$ 
Our estimate of the prevalence of inherited protein $\mathrm{C}$ deficiency in portal vein thrombosis $(2 \%)$ is higher than the figures reported for thrombosis of unselected site. ${ }^{66}$ We propose that levels of protein $\mathrm{C}$, as well as protein $\mathrm{S}$ and antithrombin III, be measured in patients with portal vein thrombosis, when no overt cause is present.

Prevention of recurrent thrombosis by coumarin derivatives is mandatory in patients with hereditary deficiency in protein C. Management of patients with previous variceal bleeding appears particularly difficult, however. Portosystemic shunting is usually not feasible in patients with portal vein thrombosis. ${ }^{1-3}$ In the present case, we reasoned that propranolol may prevent recurrent variceal bleeding. ${ }^{3.3}$ Endoscopic sclerotherapy may also be considered. The risk of bleeding from oesophageal ulcers after sclerotherapy ${ }^{34}$ might be increased by anticoagulation. This concern led to the use of propranolol as a first line method.

We thank Dr Parquet-Gernez (CDTS Lille) for performing functional and immunological assays of protein C in subjects II-1, III-3, and III-4.

\section{References}

1 Aldrete JS, Slaughter RL, Han SY. Portal vein thrombosis resulting in portal hypertension in adults. $\mathrm{Am} \mathrm{J}$ Gastroenterol 1976; 65: 236-43.

2 Webb LJ, Sherlock S. The aetiology, presentation and natural history of extrahepatic portal venous obstruction. Q J Med 1979; 48: 627-39.

3 Whitte CL, Brewer ML, Witte MH, Pond GB. Protean manifestations of pylethrombosis. A review of thirty four patients. Ann Surg 1985; 202: 191-202.

4 Griffin JH, Evatt B, Zimmerman TS, Kleiss AJ, Widemann C. Deficiency of protein $\mathrm{C}$ in congenital thrombotic disease. J Clin Invest 1981; 68: 1370-3.

5 Bertina RM, Broekmans AW, Van Der Linden IK, Mertens K. Protein C deficiency in a Dutch family with thrombotic disease. Thromb Haemost 1982; 48: 1-5.

6 Horellou MH, Conard J, Bertina RM, Samama M. Congenital protein $\mathrm{C}$ deficiency and thrombotic disease in nine French families. Br J Med 1984; 289: 1285-7.

7 Barbui T, Finazzi G, Mussoni L, et al. Hereditary dysfunctional protein $\mathrm{C}$ (protein $\mathrm{C}$ Bergamo) and thrombosis. Lancet 1984 ; ii: 819.

8 Wintzen AR, Broekmans AW, Bertina RM, et al. Cerebral haemorrhagic infarction in young patients with hereditary protein $\mathrm{C}$ deficiency: evidence for 'spontaneous' cerebral venous thrombosis. $\mathrm{Br}$ Med $\mathrm{J}$ 1985; 290: 350-2.

9 Pabinger-Fasching I, Bertina RM, Lechner K, Niessner $\mathrm{H}$, Korninger $\mathrm{C}$. Protein $\mathrm{C}$ deficiency in two Austrian families. Thromb Haemost 1983; 50: 810-3.

10 Lefrançois C, Derlon A, Sillard B, Leroy G, Marchand
P. Déficit constitutionnel en protéine C. Rôle dans la survenue d'un infarctus veineux mésentérique. Presse Méd 1985; 14: 548-9.

11 Stenflo J. A new vitamin K-dependent protein: purification from bovine plasma and preliminary characterization. J Biol Chem 1976; 251: 355-63.

12 Fair DS, Marlar SA. Biosynthesis and secretion of factor VII, protein $C$, protein $S$, and the protein $C$ inhibitor from a human hepatoma cell line. Blood 1986; 67: 64-70.

13 Owen WG, Esmon CT. Functional properties of an endothelial cell cofactor for thrombin. Catalyzed activation of protein C. J Biol Chem 1981; 256: 5532-5.

14 Esmon CT, Owen WG. Identification of an endothelial cell cofactor for thrombin-catalyzed activation of protein C. Proc Natl Acad Sci USA 1981; 78: 2249-52.

15 Marlar RA, Kleiss AJ, Griffin JH. Human protein C: inactivation of factor $\mathrm{V}$ and VIII in plasma by the activated molecule. Ann NY Acad Sci 1981; 370: 303-10.

16 Sakata Y, Curriden S, Lawrence D, Griffin JH, Loskutoff DJ. Activated protein $C$ stimulates the fibrinolytic activity of cultured endothelial cells and decreases antiactivator activity. Proc Natl Acad Sci USA 1985; 82: 1121-5.

17 D'Angelo A, Lockhart MS, D’Angelo SV, Taylor FB. Protein $S$ is a cofactor for activated protein $C$ neutralization of an inhibitor of plasminogen activation released from platelets. Blood 1987; 69: 231-7.

18 Valla D, Casadevall N, Lacombe C, et al. Primary myeloproliferative disorder and hepatic vein thrombosis. A prospective study of erythroid colony formation in vitro in 20 patients with Budd-Chiari syndrome. Ann Intern Med 1985; 103: 329-34.

19 Bertina RM, Broekmans AW, Krommenhoek-Van Es C, Van Wijngaarden A. The use of a functional and immunologic assay for plasma protein $\mathrm{C}$ in the study of the heterogeneity of congenital protein $\mathrm{C}$ deficiency. Thromb Haemost 1984; 51: 1-5.

20 Martinoli JL, Contant G, Guichaoua JF, Amiral J. Performance of a new clot based functional protein $\mathrm{C}$ assay [Abstract]. Thromb Res 1986; suppl 6: 163.

21 Boyer C, Rothschild C, Wolf M, Amiral J, Meyer D, Larrieu MJ. A new method for the estimation of protein C by Elisa. Thromb Res 1984; 36: 679-89.

22 Bezeaud A, Griffin JM, Guillin MC. Protéine C Physiologie et pathologie. In: Progrès en Hématologie. Paris: Douin, 1986: 53-62.

23 Obegard DR, Lie M, Abilgaard U. Heparin cofactor activity measured with an amidolytic method. Thromb Res 1975; 6: 872-34.

24 Friberger P, Knos M, Gustavsson S, Aurell L, Claveson G. Methods for determination of plasmin, antiplasmin and plasminogen by means of substrate S2251. Haemostasis 1978; 7: 38-45.

25 Abilgaard U, Larsen ML. Assay of dermatan sulfate cofactor (Heparin cofactor II) activity in human plasma. Thromb Res 1984; 35: 257-66.

26 Broekmans AW, Veltkamp JJ, Bertina RM. Congenital protein $\mathrm{C}$ deficiency and venous thromboembolism. A study of three Dutch families. N Engl J Med 1983; 309: 340-4. 
27 Griffin JH, Mosher DF, Zimmerman TS, Kleiss AT. Protein $\mathrm{C}$, an antithrombotic protein, is reduced in hospitalized patients with intravascular coagulation. Blood 1982; 60: 261-4.

28 Thompson EN, Williams R, Sherlock S. Liver function in extrahepatic portal hypertension. Lancet 1964; ii: 1352-6.

29 Sas G, Blaski G, Petro I, Griffin JH. A protein S deficient family with portal vein thrombosis. Thromb Haemost 1985; 54: 724.

30 Broeckmans AN, Van Rooyen W, Westerveld BD, Briet E, Bertina RM. Mesenteric vein thrombosis as presenting manifestation of hereditary protein $\mathrm{S}$ deficiency. Gastroenterology 1987; 92: 240-2.

31 Peters TG, Lewis JD, Filip J, Morris L. Antithrombin
III deficiency causing postsplenectomy mesenteric venous thrombosis coincident with thrombocytopenia. Ann Surg 1977; 185: 229-31.

32 Gruenberg SC, Smallridge RC, Rosenberg RD. Inherited antithrombin III deficiency causing mesenteric venous infarction. A new clinical entity. Ann Surg 1975; 181: 791-4.

33 Lebrec D, Poynard T, Bernuau J, et al. A randomized controlled study of propranolol for prevention of recurrent gastrointestinal bleeding in patients with cirrhosis: a final report. Hepatology 1984; 4: 355-8.

34 Ayres SJ, Goff JS, Warren G, Schaefer JW. Esophageal ulceration and bleeding after flexible fibreoptic esophageal vein sclerosis. Gastroenterology 1982; 83: 131-6. 